\title{
New Risks and the Reframing of Local Welfare as Social Investment: The Case of the FORJAD Program in Switzerland
}

\author{
Luca Martignani \\ Department of Sociology and Business Law, University of Bologna, Bologna, Italy \\ Email: luca.martignani@unibo.it \\ Received 22 September 2015; accepted 3 January 2016; published 6 January 2016 \\ Copyright (C) 2016 by author and Scientific Research Publishing Inc. \\ This work is licensed under the Creative Commons Attribution International License (CC BY). \\ http://creativecommons.org/licenses/by/4.0/ \\ (c) (i) Open Access
}

\begin{abstract}
FORJAD (Formation Professionelle pour le Jeunes Adults en Difficulté) was a program of social policy implemented in Switzerland since 2006. Its specific aim is to sustain the professional training of young unemployed adults (18 - 25) in order to allow them to become autonomous from the social assistance and to (re)entry into the labour market. This paper deals with specific dimensions of this program, with particular reference to its complex and plural governance and to the cultural framework of the Social Investment Welfare State (SIWS). This paradigm tries to connect the logics of activation and training with the necessity to realize a better quality of welfare services and to invest in personal capabilities of welfare recipients. In this framework, FORJAD seems to represent a social innovation realized to contrast at a local level the young unemployment as an example of emergent new social risks.
\end{abstract}

\section{Keywords}

Social Risks, Social Investment Welfare State, Activation, Local Welfare, Social Innovation

\section{Introduction}

The FORJAD program (Formation Professionelle pour le Jeunes Adults en Difficulté) was a social policy project active in the canton of Vaud (Switzerland) since 2006 to support those young adults (18 - 25 years) receiving social assistance and providing them with adequate professional training for their re-entry into the labour market ${ }^{1}$.

\footnotetext{
${ }^{1}$ I wish to thank the people who, for various reasons, have participated in my course of study, research and reflection at the Institute des hautes études en administration publique (IDHEAP, Université de Lausanne). I would like to mention in particular Giuliano Bonoli (IDHEAP); Cyrielle Champion (IDHEAP); Delia Pisoni (IDHEAP); Emanuelle Cuendet (Département de la Santé et de l'Action Sociale); Antonello Spagnolo (Département de la Santé et de l'Action Sociale) and Donatella Morigi (TEM-Accent). Without their help I would not have been able to write this essay, the limits of which are exclusively my fault.
} 
This objective is consistent with a political culture oriented towards the overcoming of care and the promotion of the autonomy of the recipients through an innovative governance of social inclusion measures. Indeed, with the FORJAD program, the recipients are no longer dependent on social assistance, instead qualifying for a scholarship from the canton. This aspect will be crucial to investigate the most interesting and potentially innovative features of the project, both structurally and culturally.

In the next section, we will introduce the problem for which this policy is launched, first as an experiment, then as a system policy. We will also present the context of the program, with particular reference to the aspects and logics of care and social inclusion. The third section will instead focus on policy design and project governance, in order to highlight its peculiarities and main actions, as well as the coordination logic between the actors involved. In the fourth paragraph, we will take into account the social significance of the program. We will explain its objectives and culture of reference, which for some essential aspects are ascribable to the theory of welfare state as a social investment (SIWS). In the fifth paragraph, the attention will focus on the territorial roots, in order to highlight its strengths and weaknesses. Finally, the conclusions summarize the significant features of FORJAD, following an argument that points to the need to explore the relationship between investment and social innovation.

\section{Problem and Context}

The FORJAD program was introduced on an experimental basis in the canton of Vaud in 2006. Its design is a part of social inclusion, one of the areas in which Switzerland has been affected by profound changes. As highlighted in a recent study by Bonoli \& Champion (2012), the total number of welfare recipients has increased from 88,000 people in 1990 to as many as 231,000 in 2010. This is therefore a sector whose action, unlike the past, is not limited to residual interventions, becoming instead a structural axis of the welfare state, which finds expression in specific social policy measures. The reasons behind these developments can be found mainly in the economic crisis that Switzerland has faced in the late nineties and in the transformation of employment contracts regulations. These factors have resulted in the emergence of rather weak social categories, such as working poors, long-term unemployed or disadvantaged young adults. No wonder then that we can observe at the same time a growth in the number of beneficiaries of assistance and a tendency to favour an active approach to social inclusion, characterized by its insistence on reintegration and not on passive measures such as benefits and welfare payments. The FORJAD program fits into this framework in order to meet the problems of social and professional inclusion of disadvantaged young adults.

Let's see the policy context in detail. Project implementation was accelerated not only by data showing the presence of a social group at risk, but also by the awareness that the condition of disadvantaged young adults (JAD) is an emergent effect of a multidimensional problem. Among the causes of this phenomenon, the persons charged with compiling a first dossier drawn up in August 2007 (Von Murait \& Spagnolo, 2007) mention: a labour market that has become extremely selective; a number of apprenticeship places not suitable to demographic changes; the steady growth of family breakdowns. It is also in view of this complexity that the Federal Law on employment services stipulates that all people able to work and seeking employment can join a regional placement office (office regional de placement, ORP henceforth) and benefit from personalized support. The problem of disadvantaged young adults also requires the cooperation of the various actors involved in managing this risky situation that confronts the challenge of social inclusion of this category through solutions able to cover the complex issues dotting its life cycle. In the canton of Vaud, these risks were initially addressed through the reorganization of the revenu d'insertion (RI henceforth). It is a measure of social protection resulting from the merger between two previous contributions: the aide sociale vaudoise (ASV) and the guaranteed minimum income (revenu minimum d'insertion, RMR). As underlined by Maillard \& Müller (2012), the RI is a selective instrument, subject to a means test, which occurs only when the subject's private resources (income and annuities) are depleted and the financial support provided at the cantonal level is inadequate to ensure the minimum income essential to secure the subject a dignified existence (Maillard \& Müller 2012: p. 120). RI offers support to all disadvantaged persons in the form of financial aid designed to ensure a vital minimum, to which are attached specific measures aimed at employment or re-employment, in particular through vocational training.

This is the policy context in which FORJAD is situated. The program, started as an experiment with an estimated budget of 4 million CHF, is the result of the agreement and joint action of three institutional actors: the 
Département de la Santé et de l'Action Sociale (DSAS), the Département de la Formation, de la Jeunesse et de la Culture (DFJC) and the Département de l'Economie (DEC). Despite the encouraging results shown by the program (Jaques, 2012: p. 136), the situation that FORJAD is facing is rather problematic, so that Spagnolo (2014), Chef Section Aide et Insertion Sociale at the Département de la Santé et de l'Action Sociale of Lausanne calls it disturbing. The data updated in March 2014 indeed show a situation where more than 3200 young adults (18 - 25 years) depend on RI. Among them, 70\% do not have an appropriate vocational training (against 12\% of the total population of the Canton of Vaud). So this is a segment of the population and a social category with a very high risk of exclusion. Moreover, these data represent a critical situation also from the point of view of local government, as the protection of that population group costs about 60 million Swiss francs (CHF) per year, a figure equal to $15 \%$ of the costs for social care faced by the State and the municipalities included in it.

\section{Project Structure: Its Resources and Governance}

The FORJAD program governance is rather complex and is certainly an example of plural welfare inspired by a new form of democracy (Sabel \& Zeitlin, 2012; Sabel, 2013), able to coordinate in an articulated project actors of a different kind, to enhance the contribution of civil society in the governance of the program, and to boost mutual monitoring among the various stakeholders. Specifically, the program consists of three different phases, happening in sequence yet integrated in an organic manner.

1) Preliminary stage. It entails the preparation of disadvantaged young adults and their introduction to apprenticeships through integration measures specifically prepared (MIS JAD). At this juncture, the process of inclusion of the recipients means elaborating and completing of their professional project, searching for a training place, and upgrading their academic skills.

2) Vocational training. This stage gets into the real core of the program. After finding a suitable training place, if the young adults concerned possess the required qualifications ${ }^{2}$, they can join the FORJAD program. A personalized program of mentoring and monitoring of individual paths is thus implemented by qualified advisers offering their support over four areas: (a) professional (mediation and enterprise); (b) educational (educational and pedagogical support); (c) personal (monitoring of the behaviour through the training process and of eventual barriers to its successful completion); (d) social (social and administrative support). At the same time, an application for a scholarship is forwarded to the competent office (OCBE) to facilitate the end of the recipients' reliance on the RI.

3) Placement. At the end of the training, the recipients can continue to benefit from the guidance of their mentor for a period of three months (the so-called post-training period). During this time two scenarios can take place: either the search for a job, or the monitoring of the young adult's integration in his new professional environment (if she has already found a job).

The crucial stages of the FORJAD program—such as vocational training and placement—are strongly characterized by the active role of the TEM-Accent association (Transition École Métier, Accompagnement en Entreprise). It is a training organization whose members follow the path of the young adults involved in the project, thus crucially linking the training stage and that of the recipients' professional employability. In addition, every year it monitors the project's progress, producing interesting information on its strengths and weaknesses. These elements will be dealt with in the sixth paragraph.

\section{Social Significance of the Project: Its Goals and Culture of Reference}

The FORJAD program is aimed at young people aged 18 - 25 years who benefit from RI and intend to obtain adequate professional training to leave their assisted condition behind. The objectives of the program, already highlighted by Spagnolo (2014), are: (1) facilitating access to certify and high-quality training; (2) allowing a scholarship to foster independence from social assistance; (3) following the recipients through a structured process of monitoring (follow up). It is therefore appropriate to place the program in the context of active labour market policies.

However, this location logic must be specified not only in relation to the specific objective, but also with ref${ }^{2}$ The requirements for the FORJAD program are: (1) being aged between 18-25 years; (2) being the beneficiaries of RI; (3) requiring personalized support as part of the training process; (4) not having completed a course of study; (5) formulating a realistic and achievable career plan, validated by a social worker. 
erence to the fact that activation-like family-work balance and the vocational programs-is increasingly the expression of a paradigm shift of welfare programs in the face of new social risks, rather than the specific targets of individual policy measures ${ }^{3}$.

First, the FORJAD system corresponds to a job placement culture oriented towards the promotion of autonomy and responsibility. So far, however, nothing new: the active labour market policies are often implemented following this explicit imperative. We should rather emphasize that the overcoming of the care paradigm to which the project aspires is pursued through specific methods of involvement of the actors involved. These methods lie in the explicit full legitimacy recognized as part of the design of policy to every single actor (the State, local government, civil society, the world of work, single recipients, training institutions). If it is true that the RI was introduced in accordance with the principle of subsidiarity-according to whose interpretation the RI is granted only when cantonal resources and the personal ones of the subject are exhausted-it is also true that this interpretation of the principle is extremely reductive. Sure enough, it does not take into account the socioanthropological foundations of the concept (Donati \& Colozzi, 2005; Donati, 2011), merely describing the mechanism for transferring money according to a hierarchy of responsibility limited to the sphere of action of the public administration. The FORJAD program substantiates the subsidiary profile acquired by labour policies. In addition to the vertical dimension to which the RI is restricted, it represents a horizontal dimension with the involvement of public and private stakeholders in achieving the objectives of the program. The actors involved naturally have different functions, but they also have the same capacity to act on a specific segment of the policy draft, sharing with others the relevant information for each stage, continually re-orienting their actions and re-stating their goals in a synergistic and personalised way ${ }^{4}$. So, while not a policy coming from below, FORJAD draws attention to the autonomy and empowerment of individuals and also to the role of non-state actors (such as the civil society) in participating in the construction of an integrated policy model. The logic of personalisation found in some stages of the program—such as the sharing of information, mutual monitoring among stakeholders, and continuous re-specification of the objectives of the policy with respect to the challenges of the social environment-is also the focus point of some of Charles Sabel's considerations on democratic experimentalism (2013). Indeed, FORJAD shows interesting elements thus oriented (especially with respect to the construction of the personalized program of intervention and the mutual monitoring between government, civil society and the beneficiaries). However, as we will see below, the emphasis on the activation as a strategic key for the development of more effective social policies (Bonvin \& Orton, 2009), seems to keep any consideration on customisation of welfare on the background, suggesting instead the topic of social investment as the new narrative of contemporary eurocracy. Activation, work-life balance and longlife learning are the strategic axes underpinning a new interpretation of welfare regimes focusing on social investment (Social Investment Welfare State, SIWS henceforth) (Morel, Palier, \& Palme, 2012; Hemerijck, 2013: pp. 373-398). The culture behind FORJAD is in fact in my opinion in conformity with this setting and - more generally—with the H2020 strategy aimed at promoting inclusive growth and social cohesion through innovations in social policy.

But what is exactly SIWS? It is a paradigm recently developed by some scholars (Hemerijck, 2012; Morel, Palier, \& Palme, 2012: pp. 355-356) corresponding to a sort of third stage in the changes that have affected the history of contemporary welfare regimes. The first stage corresponds to the Keynesian paradigm, which has found a strong expansion since the end of World War II until the economic crisis generated by the oil shock following the Yom Kippur War. These thirty glorious years (1945-1975) were then followed by a stage characterized by a much less generous welfare state and with a neo-liberal connotation. Rationalization of costs was thus associated with a policy of privatization of services and the deregulation of the labour market. As a consequence, these strategies have led to the development of the rhetoric of activation seen as logic according to which welfare entitlements and provisions are to be linked to an active workfare. The third stage, a concept recently reworked, is in my view a synthesis (or a third way) between the virtuous aspects of the first model (social equity as a logic of inclusion, positive representation of social policy as a lever for development and support to the most vulnerable segments of the population) and the characteristic elements of the second one (individual responsibility, the importance assigned to work as a strategy to overcome the systematic recourse to social assistance, the idea of autonomy and freedom of choice). The characteristics of this third stage are summarized in Table 1 . SIWS therefore wants to combine social inclusion and activation through strategies oriented toward the investment in human capital as a lever for the development of a welfare paradigm able to acknowledge individual skills, en-

${ }^{3}$ On the "activation turn” in the european social policies' area see Bonvin \& Favarque (2007) and also Borghi (2011).

${ }^{4}$ On welfare customisation see Prandini (2013); Orlandini (2013) and Martignani (2013). 
Table 1. Paradigms, principles and policies: three paradigms compared.

\begin{tabular}{|c|c|c|c|}
\hline & Keynesian paradigm & Neo-liberal paradigm & Social investment (SIWS) \\
\hline Causes of unemployment & Insufficient demand & Rigidities in the labour market & Lack of appropriate skills \\
\hline $\begin{array}{l}\text { Guiding values } \\
\text { and principles }\end{array}$ & $\begin{array}{c}\text { Social equity } \\
\text { work for everyone } \\
\text { de-commodification }\end{array}$ & $\begin{array}{l}\text { Individual responsibility any job } \\
\text { activation }\end{array}$ & $\begin{array}{l}\text { Social inclusion more and better jobs } \\
\text { capacitation equal opportunities } \\
\text { prepare rather than repair }\end{array}$ \\
\hline $\begin{array}{l}\text { Norms underlying } \\
\text { public action }\end{array}$ & $\begin{array}{l}\text { Big state } \\
\text { growth of the welfare state }\end{array}$ & $\begin{array}{l}\text { Lean state } \\
\text { dismantling of the welfare state }\end{array}$ & $\begin{array}{l}\text { Empowering state } \\
\text { reconfiguration of the welfare state }\end{array}$ \\
\hline Main tools & $\begin{array}{l}\text { Demand support } \\
\text { insurances } \\
\text { income support }\end{array}$ & $\begin{array}{l}\text { Monetarist policies } \\
\text { deregulation } \\
\text { privatization workfare }\end{array}$ & $\begin{array}{l}\text { Human capital } \\
\text { development of services for access to } \\
\text { employment flexicurity }\end{array}$ \\
\hline
\end{tabular}

Source: personal elaboration from Morel, Palier, \& Palme, 2012: pp. 12-13.

sure equal opportunities in access to services and professions, and promote actions designed to foster individual skills in order to stem the hypertrophic growth of the more essentially financial aspects of welfare regimes (such as direct money transfers). From the point of view of the configuration of citizenship rights, this model represents an overcoming of the of bureaucratic-hierarchical government form as described by Weber (effectively represented in the Keynesian logic) and of the privatization of services (recognisable in neo-liberalism). The spheres according to which society and welfare systems are different (government, civil society organizations, businesses, and families, in addition to individual beneficiaries) are the actors of a governance based on networking and forms of partnership aimed to create more advanced services and programs of social inclusion (Jenson, 2012: p. 75).

\section{Consolidation of the Project on the Territory: Its Strengths and Weaknesses}

Over the years, the project has strengthened its presence in the area, evolving from experimentation to structural policy. Indeed, since 2006, the young adults involved in training through FORJAD were almost two thousand (1962). To date, 690 people are currently involved in the program. Those who have obtained a diploma or a professional qualification since the start of the program were 543. Moreover, their number is growing steadily. The program boasts a success rate of $66 \%$ ( $44 \%$ attendance to training $+22 \%$ achievement of a diploma). Normally, the training offered to the recipients of the program is company-based $(70 \%)^{5}$. The remaining $30 \%$ is divided into public and private vocational schools or at training institutions. From a survey carried out in 2012 by TEM-Accent on a set of 122 young people monitored in the period after the training, 37\% received employment (45), while $40 \%$ of them (49) were still in search employment.

Among the strengths of the project, we can include: (1) a solid political agreement among the stakeholders involved, from the three departments that have created the institutional frame of the project; (2) the budget of CHF 8 million allocated to start the program; (3) a sum of 2300 francs per month for each recipient involved in the early stages of taking in charge, training, supervision and placement before and after the training phase (there is a coach every 23 apprentices to facilitate prompt and personalised training activities). In addition to the economic and political dimension of the project, its organization and governance also have specific strengths, as maintained by Emmanuelle Cuendet, one of the representatives of the project at the Département de la Santé et de l'Action Sociale. First, the cantonal organization allows coordination and a prompt management of the program. Second, the collaboration between the organizations involved, the specialized coaching system, and the employment agencies constitute a solid partnership. The evaluation of reintegration practices is another key point. As explained by Donatella Morigi (TEM-Accent referent for monitoring FORJAD) monitoring takes place through three different stages. The first takes place immediately after the formation, and relates with expectations of professional integration and management of the transition to the employment contract. The second takes place after four months and aims to provide an initial overview of how the connection between education and the labour market is working.

${ }^{5}$ The areas involved are mainly: trade, transports and tourism (31\%); industry and handicraft (20\%); building and constructions (17\%); health (15\%); catering and hotel accommodation (7\%); communication, arts, and human sciences (4\%); textile industry (4\%); environment $(2 \%)$. 
Finally, a third stage takes place 15 months after the end of the training, in order to identify whether and in which cases there is a stabilization of the occupational profile of the recipients and when instead they leave once again the labour market, with the risk of reverting to their reliance on benefits. These features allow us to place the FORJAD program in a rather evolved scenario for what concerns the strategic axis of active labour market policies (or Active Labour Market Social Policies, ALMSP henceforth). If we refer to the ALMSP types identified by Bonoli (2012: pp. 184-185) FORJAD is characterized by a strong investment in human capital as a basic condition for access to the labour market. The virtuous interplay between access requirement and target defines an up-skilling-type scenario ${ }^{6}$.

Among the weaknesses, the difficulty of the recipients involved in the program in finding a job, despite the good result of the previous training program has been highlighted since 2009 (the year of publication of a dossier on the budget for the first three years of the project, see Mûller, Cretin, Durrer, \& Spagnolo (2009). In addition to this structural weakness, sometimes the recipients show lack of confidence in the school system and relationship or behavioural problems, often related to difficult family circumstances, substance dependence, or-in some cases-mental health issues.

\section{Conclusion: Investment and Social Innovation}

In this essay, we examine a rather specific social policy program, which nonetheless also presents some essential features of the overall paradigm of welfare as social investment in the face of new risks emerging from the economic and political context. In short, we can conclude that FORJAD is a measure interpreting the social inclusion of welfare recipients as an employment-oriented kind of support (prise en charge orientée vers l'emploi) (Bonoli \& Champion, 2013). If the philosophy underpinning the program is clear and technically ascribable to the SIWS paradigm, it is nevertheless important to wonder about another key issue for the transformation of the welfare system: is this an innovative program?

First, we need to define what is meant by social innovation with respect to welfare policies. If we accept the idea recently introduced by Maino (2013), according to which an intervention is innovative if and when it is new, effective, and sustainable, it will be fairly easy to consider FORJAD as an innovative project, also considering the territory on which it is implemented. However, it is essential to understand how the program can be a social innovation, also with reference to the paradigm under which it is implemented.

A recent attempt to relate investment and social innovation with reference to welfare regimes has been offered by Jenson (2014). According to the author, it is important to connect these two issues to understand the logic by which the instruments and the governance of social policies are re-drawn in the light of new social risks. In other words, the reconfiguration of welfare as social investment represents a paradigm shift that aims to introduce innovative tools in order to promote more effective forms of cohesion and social innovation. It is at this juncture that civil society can play a pro-social role in reconfiguring the design of specific policy programs and the governance of new welfare experiments.

From the point of view of governance, it is essential to emphasize that the FORJAD program is an interesting experiment in the co-production ${ }^{7}$ of work support strategies. Indeed, social innovations (also in the field of welfare) result in new ideas, methods, and techniques, but also in new practices (Pestoff, 2015). Such practices are aimed at: (1) overcoming the boundaries of the individual organizations involved in order to create networks of actors oriented towards a common goal (in the case of FORJAD, this refers to the relationship between government, civil society, labour market, and the recipients themselves); (2) mobilizing new resources for the purpose of enhancing the performance of individual services (in the case of FORJAD it comes to allocate part of the cantonal social spending to an active policy intervention); (3) providing for a change in the tools employed (in the case of FORJAD, the transition from RI to a scholarship and the inclusion in training courses); (4) changing the configuration of the decision-making process (in the case of FORJAD, the cantonal administration uses TEM-Accent's evaluation reports and analysis) and; (5) considering and evaluating major issues related to the

\footnotetext{
${ }^{6}$ Not all the ALMSPs fall within this scenario. With reference to previous studies (Martignani, 2006, 2007, 2012) is possible to state that certain measures started by the ESF 2000-2006 and 2007-2013 are of the employment assistance type. These measures are not characterized by the investment in human capital but by being explicitly aimed at removing obstacles to female participation in the labour market.

${ }^{7}$ The concept of co-production has been developed for the first time by Ostrom (1996) to describe and identify the involvement of citizens in the production of services of public interest. The co-production is therefore the relationship that can potentially be established between the producers of services (such as public bodies, but also civil society organizations) and recipients (Pestoff, 2009, 2015) that may be affected by a change of status: from "assisted” to prosumer of services.
} 
distribution of wealth in the social context (with respect to the FORJAD example, the follow-up action on the recipients is crucial). FORJAD is therefore a project that gives its recipients more freedom of choice with respect to its path of inclusion, at the same time providing them the opportunity to voice their opinions, decisions, and aspirations concerning the job they will like to get (and consequently the training they will face).

The analysis conducted by Adalbert Evers and his associates (Evers \& Ewert 2015)_involved in an international research program funded by the European Union called Welfare Innovations at the Local Level in Favour of Cohesion (WILCO) — show that social innovations consist of those new practices that attract the hopes and aspirations of the actors involved (towards something better) but that are at the same time risky and whose outcome is uncertain due to the high dependence on the socio-economic context in which they are implemented. The FORJAD program seems to perfectly fit this conceptual framework.

From the analytical stance, Evers \& Ewert (2015) identify five basic dimensions useful to investigate the innovations of welfare at the local level: (1) type of services and how their recipients are involved; (2) rules and rights; (3) governance and policy design; (4) logic of funding and mix of resources; (5) transformation of the local welfare. (1) Regarding the first point, it is easy to see how the FORJAD program introduces a meta-care, enabling logic for its recipients. This is crucial from the point of view of the co-production of services (Pestoff, $2009,2015)$ as much as that of the investment in active policies, which is one of the fundamental issues of SIWS (prepare rather than repair). (2) With respect to second point, the innovative nature of the project is expressed in the fact that for the recipient to obtain/get a degree/qualification is the promotion of an active profile and means his change of status from "assisted" to "learner". This is especially important if we interpret FORJAD's upskilling logic of as an attempt to respond to new social risks, such as youth unemployment (Bonoli, 2005). (3) The governance of the project has an innovative profile because-in addition to involving government, civil society, and beneficiaries in the project-it employs specific procedures (such as follow-up and accountability of the project performance by MET-Accent) that promote a system of checks and balances between the parties involved thus perfecting the democratic status of the program (Sabel, 2013). (4) Regarding the mode of financing, the considerations mentioned in the second point can also be applied: the change in the condition of the recipient from "assisted" to "learner" takes place precisely by changing the logic of funding contributions. RI is replaced with a scholarship. This triggers a different procedure of inclusion and prise en charge by the policy for what concerns the recipient and its training and employment needs. (5) The above points highlight that FORJAD may represent an interesting transformation of local welfare and an example of investment in innovation given his enabling characteristics and its aim to promote the capabilities of those involved (Bonvin \& Orton, 2009; Nussbaum, 2011; trans. It. 2012).

The analysis above thus shows some key points that can give the project an innovative character.

The first one concerns the relationship between the political and administrative structures. In fact, the collaboration between different departments that have first promoted, then accelerated its testing, and finally established the FORJAD program, represents an element that political scientists and public policy analysts believe - and rightly so - to be an enabling aspect facilitating the structuring of each measure on a given area. At the same time, given that the fact that the strength of a social policy depends on the efficiency of the public administration, it follows that this type of analysis often risks to anchor the innovative nature of the interventions to the fragmentation of administrative contexts.

The second innovative aspect concerns instead the role of civil society, and in particular of TEM-Accent, with regard to training and follow-up on the recipients. This action also results in a closer relationship between government, civil society organizations, and recipients in achieving an inclusive program, able (1) to enhance the needs actually experienced by its applicants, and (2) to strengthen the collaboration between different subjects united in their wish to invest in measures forestalling such a significant social risk as youth unemployment.

These aspects are joined by a third one, which is the political and social culture that guides the project in a capability building and meta-care direction. For the young beneficiaries of RI to leave their assisted condition is a goal which corresponds to a culture of autonomy promoted by the SIWS, and which finds full expression in the change of status of the recipients from "assisted" to "learners".

This element, besides suggesting the orientation of a program that tends to co-production of accompanying services at work (Pestoff, 2015) results in a semantics of subsidiarity not only vertical or "defensive" but also horizontal (Colozzi, 2002; Donati, 2003), able to synergistically decline the role of public and private actors cooperating in the creation of a more effective measure of social inclusion. 


\section{References}

Bonoli, G. (2005). The Politics of the New Social Policies: Providing Coverage against New Social Risks in Mature Welfare States. Policy \& Politics, 33, 3.

Bonoli, G. (2012). Active Labour Market Policy and Social Investment: A Changing Relationship. In N. Morel, B. Palier, \& J. Palme (Eds.), Towards a Social Investment Welfare State? Ideas, Policies and Challenges (pp. 181-204). Bristol: Policy Press.

Bonoli, G., \& Champion, C. (2013). La réinsertion professionnelle des bénéficiaires de l'aide sociale en Suisse et en Allemagne (p. 281). Lausanne: Caheir de l’IDHEAP.

Bonvin, J.-M., \& Favarque, N. (2007). A Capability Approach to Individualised and Tailor-Made Activation. In R. van Berkel, \& B. Valkenburg (Eds.), Making It Personal: Individualilsing Ativation Services in the EU (pp. 45-66). Bristol: Policy Press. http://dx.doi.org/10.1332/policypress/9781861347978.003.0003

Bonvin, J.-M., \& Orton, M. (2009). Activation Policies and Organisational Innovation. The Added Value of the Capability Approach. International Journal of Sociology and Social Policy, 29, 565-574.

http://dx.doi.org/10.1108/01443330910999014

Borghi, V. (2011). One-Way Europe? Institutional Guidelines, Emerging Regimes of Justification and Paradoxical Turns in European Welfare Capitalism. European Journal of Social Theory, 14, 321-341. http://dx.doi.org/10.1177/1368431011412348

Colozzi, I. (2002). Le nuove politiche sociali. Roma: Carocci.

Donati, P. (2003). Sociologia delle politiche familiari. Roma: Carocci.

Donati, P. (2011). I fondamenti socio-antropologici della sussidiarietà: una prospettiva relazionale. In Id. (a cura di), Verso una società sussidiaria. Teorie e pratiche della sussidiarietà in Europa (pp.), Bologna: Bononia University Press.

Donati, P., \& Colozzi, I. (a cura di) (2005). La sussidiarietà. Cos'è e come funziona. Roma, Carocci.

Evers, A., \& Ewert, B. (2015). Social Innovations on the Local Level. Approaches, Instruments and Differents Ways of Dealing with Them. In P. Donati, \& L. Martignani (Eds.), Towards a New Local Welfare: Best Practices and Networks of Social Inclusion (pp. 15-42). Bologna: Bononia University Press.

Hemerijck, A. (2012). Two or Three Waves of Welfare State Transformation? In N. Morel, B. Palier, \& J. Palme (Eds.), Towards a Social Investment Welfare State? Ideas, Policies and Challenges (pp. 33-60). Bristol: Policy Press.

Hemerijck, A. (2013). Changing Welfare States. Oxford: Oxford University Press.

Jaques, F. (2012). Le nouvelles orientations de l'action sociale vaudoise: Pour un service public de la deuxième chance. In J. P. Tabin, \& F. X. Merrien (Eds.), Regards croisés sur la pauvreté (pp. 131-137). Lausanne: EESP.

Jenson, J. (2012). Redesigning Citizenship Regimes after Neoliberalism: Moving towards Social Investment. In N. Morel, B. Palier, \& J. Palme (Eds.), Towards a Social Investment Welfare State? Ideas, Policies and Challenges (pp. 61-87). Bristol: Policy Press.

Jenson, J. (2014). Reworking the Socials: Four Intersecting Concepts for Modernising Social Policy. Proceedings of the International Conference on Assessing the Social Investment Strategy, Lausanne, 10-11 April 2014.

Maillard, P. Y., \& Müller, P. (2012). La politique vaudoise de lutte contre la pauvreté: Objectifs et réalisations de la législature 2007-2012. In J. P. Tabin, \& F. X. Merrien (Eds.), Regards croisés sur la pauvreté (pp. 119-129). Lausanne: EESP.

Martignani, L. (2006). I voucher di conciliazione dei tempi e la promozione delle Pari Opportunità. Quale ruolo per la famiglia? Il Progetto Futura della Regione Friuli Venezia Giulia. In P. Donati, \& R. Prandini (Eds.), Buone pratiche e servizi innovativi per la famiglia: Nuove sinergie tra pubblico, privato e terzo settore (pp. 245-275). Milano: Franco Angeli.

Martignani, L. (2007). Il ruolo del voucher nella ricerca di buone pratiche di conciliazione. In P. Donati (Ed.), Famiglia e bisogni sociali: La frontiera delle buone prassi (pp. 366-389). Milano: Franco Angeli.

Martignani, L. (2012). Tra workfare e capacitazione. Le semantiche della conciliazione famiglia-lavoro promosse tramite dispositivi e buoni di servizio. In P. Donati (Ed.), La famiglia in Italia. Sfide sociali e innovazioni nei servizi (pp. 139-167). Roma: Carocci.

Martignani, L. (2013). Un esempio di welfare personalizzato? Il sistema dotale della Regione Lombardia. Sociologia e politiche sociali, $16,135-157$.

Morel, N., Palier, B., \& Palme, J. (2012a). Towards a Social Investment Welfare State? Ideas, Policies and Challenges. Bristol: Policy Press.

Morel, N., Palier, B., \& Palme, J. (Eds.) (2012b). Beyond the Welfare State as We Know It? In N. Morel, B. Palier, \& J. Palme (Eds.), Towards a Social Investment Welfare State? Ideas, Policies and Challenges (pp. 1-30). Bristol: Policy Press.

Morel, N., Palier, B., \& Palme, J. (Eds.) (2012c). Social Investment: A Paradigm in Search of a New Economic Model and Political Mobilisation. In N. Morel, B. Palier, \& J. Palme (Eds.), Towards a Social Investment Welfare State? Ideas, Policies and Challenges (pp. 353-376). Bristol: Policy Press. 
Mûller, L., Cretin, A., Durrer, K., \& Spagnolo, A. (2009). Programme FORJAD: Un bilan 3 ans après. Le dossier du mois de l'ARTIAS (Association Romande et Tessionoise des Institutions d'Action Sociale), Décembre 2009, 1-13.

Nussbaum, M. C. (2011). Creating Capabilities. The Human Development Approach. Cambridge, MA \& London: The Belknap Press of Harvard University Press; trad. it. Creare capacità. Liberarsi dalla dittatura del Pil, Bologna: il Mulino, 2012. http://dx.doi.org/10.4159/harvard.9780674061200

Orlandini, M. (2013). Co-produrre servizi di welfare: Semantiche ed esempi per il contesto italiano. Sociologia e Politiche Sociali, $16,111-134$.

Ostrom, E. (1996). Crossing the Great Divide: Coproduction, Synergy, and Development. World Development, 24, 10731087.

Pestoff, V. (2009). Citizens as Co-Producers of Welfare Services: Preschool Services in Eight European Countries. In T. Brandsen (Ed.), Co-Production. The Third Sector and the Delivery of Public Services (pp. 503-520). London \& New York: Routledge.

Pestoff, V. (2015). Co-Production as Social Innovation in Public Services. In P. Donati, \& L. Martignani (Eds.), Towards a New Local Welfare: Best Practices and Networks of Social Inclusion (pp. 83-111). Bologna: Bononia University Press.

Prandini, R. (2013). La persona come medium e forma di politica sociale. Un cambiamento di paradigma per i servizi di welfare. Sociologia e politiche sociali, 16, 43-78.

Sabel, C. (2013). Esperimenti di nuova democrazia. Roma: Armando.

Sabel, C., \& Zeitlin, J. (2012). Experimentalism in the EU: Common Ground and Persistent Differences. Regulation and Governance, 6, 410-426. http://dx.doi.org/10.1111/j.1748-5991.2012.01157.x

Spagnolo, A. (2014). Programme FORJAD. Presentation au Département de la Santé et de l’Action Sociale, Mars.

Von Murait, I., \& Spagnolo, A. (2007). FORJAD: L'Insertion de jeunes adultes à l'aide sociale par la formation professionelle. le dossier du mois de l'ARTIAS (Association Romande et Tessionoise des Institutions d'Action Sociale), Août 2007, 1-11. 